\title{
Apology Strategies of Iranian Undergraduate Students
}

\author{
Mohammad Dadkhah Tehrani \\ Faculty of Foreign Languages, The university of Isfahan, Isfahan 8174673441, Iran \\ E-mail: coordinator86@yahoo.com
}

Omid Rezaei

Faculty of Foreign Languages, The university of Isfahan, Isfahan 8174673441, Iran

E-mail: omidrezaei.rezaei99@gmail.com

Salman Dezhara

Faculty of Foreign Languages, The university of Isfahan, Isfahan 8174673441, Iran

E-mail: hamangt@hotmail.com

Reza Soltani Kafrani

Faculty of Foreign Languages, The university of Isfahan, Isfahan 8174673441, Iran

E-mail: r.soltani.k@gmail.com

Received: October 12, 2011

Accepted: December 19, 2011

Published: February 1, 2012

doi:10.5539/elt.v5n2p93

URL: http://dx.doi.org/10.5539/elt.v5n2p93

\begin{abstract}
This study investigated the different primary and secondary strategies the Iranian EFL students use in different situations and the effect of gender on this. A questionnaire was developed based on Sugimoto's (1995) to compare the apology strategies used by male and female students, only gender was examined as a variable. The results showed that the Statement of remorse was the strategy most frequently used by male and female respondents across the sample and female participants used this strategy more frequently than male participants. Moreover The four primary strategies used by the male respondents were accounts, compensation reparation, negative assessment of responsibility $(30 \%, 20 \%, 15 \%, 15 \%$, respectively), while those used by female respondents were compensation, Showing lack of intent to do harm, accounts, reparation $(20 \%, 20 \%, 15 \%, 10 \%$, respectively). Male respondents tended to use negative assessment of responsibility more than their females, counterparts $(15 \%$ and $5 \%$, respectively). Female respondents used the strategy of promise not to repeat offense in $10 \%$ of the situations, while their male counterparts did not use this strategy at all.
\end{abstract}

Keywords: Apology strategies, Effect of gender, EFL

\section{Introduction}

The present study is an investigation of Iranian undergraduate students' apologies. The researcher compares the strategies used by male \& female respondents for the purpose of uncovering if gender affects this or not. It should be noted that this study focuses on the use of speech act of apology by the speaker/ wrong doer; so, whether or not the hearer/offended accepts the apology is beyond the scope of this study.

Goffman (1941) defines apologies as remedial interchanges used to reestablish social harmony after a real or virtual offence. He further claims that a successful apology has several felicity conditions the most important of which are for the apologizer to acknowledge an offense has taken place, to take responsibility for that offense, and, finally, to offer some compensation for reparation. (Olshtain, 1989) defines an apology as a speech act which is intended to provide support for the hearer who was actually or potentially malefacted by a violation "When one offers an apology, one shows willingness to humiliate oneself to an extent that makes an apology a face - saving act for the hearer and a face - threatening act for the speaker

Apologies fall under expressive speech acts in which speakers attempt to indicate their state or attitude. In order for 
an apology to be effective, it should reflect true feelings. One cannot effectively apologize to another and truly reach $\mathrm{him} /$ her unless one portrays honest feelings of sorrow and regret for whatever one has done. (Gooder, \& Jacobs, 2000) point out:

The proper apology acknowledges the fact of wrong doing, accepts ultimate responsibility, expresses sincere sorrow and regret, and promises not to respect the offense.... Some of the features of the proper apology are the admission of trespass, the implied acknowledgment of responsibility, an expression of regret, and a promise of future in which injury will not recur.

The present researcher has chosen to use the strategies used by Sugimoto (1997) as the basis of data analysis.

\section{Research Questions}

This study attempts to answer the Following questions:

1. What are the primary apology strategies used by Iranian undergraduate students?

2. What are the secondary apology strategies used by Iranian undergraduate students?

3. What are the differences, if any, between the apology strategies used by male and female respondents?

\section{Related Literature}

The researcher has conducted a review of literature on apologies. This section is divided in to subsections on research on cross - cultural apologies, and research on apologies and gender.

\subsection{Research on Cross - Cultural Apologies}

Research on cross - cultural comparative discourse (olshtain 1981; olshtain, 1983) has revealed that different cultures possess different rules of appropriateness. (Olshtain, 1983) claims that events that require an apology have been shown to vary cross culturally

A good body of pragmatic research has examined apologies in different languages. Considering various variables such as the politeness strategies employed (e.g. G. Brown, 1978), the cultural values reflected in the realization of an apology (e.g. Cordella, 1990), gender (e.g. Cordella, 1990), and strategies used by native and non - native speakers (Trosborg, 1987)

Sugimoto (1997) Compared the apology styles of 200 American (79 males and (21 females) and 181 Japanese (82 males and 99 females) college students who responded to an open - ended questionnaire on situations warranting an apology. Sugimoto (1997) reported the following strategies:

I. Primary strategies are those frequently used by offenders when attempting to apologies. They include:

1. Statement of remorse in which the wrongdoer acknowledges that $\mathrm{s} /$ he has done something wrong,

2. Accounts in which the wrongdoer tells what has happened.

3. Description of damage in which the wrongdoer describes what changes have been inflicted on the object in discussion.

4. Reparation in which the wrongdoer tries to repair the damage s/he inflicted on others by offering words that may cause the harm done to be forgotten

II. Secondary strategies include:

1. Compensation, which differs from reparation in that the wrongdoer offers to replace the damaged object or pay for it, and

2. Promise not to repeat offense in which the wrongdoer does his / her utmost to assure the injured party what has taken place will not occur in the future.

III Seldom used strategies include:

1. Explicit assessment of responsibility in which the wrongdoer attempts to describe his / her role in what has happened

2. Self - castigation in which the wrongdoer claims responsibility for what has happened and is being hard on him/ herself,

3. Contextualization in which the wrongdoer describes the context of the injury in order to make the injured party see the while picture, and

4. Gratitude in which the wrongdoer is thankful that the offender is willing to give him/ her chance to explain and be forgiven. 
Sugimoto (1997) reported that the four most used strategies are statement of remorse, accounts, description of damage, and reparation. And that, with the exception of accounts, the Japanese respondents used these strategies more than their American Counterparts did. She further reported that Compensation and promise not to repeat offense were secondary strategies used mainly by Japanese respondents.

\subsection{Apologies and Gender}

Much sociolinguistics research has been conducted on gender differences in speech act realization. Empirical findings seem to suggest that gender differences do exist in apologies.

(Holmes, 1995) investigated gender differences in apologies and found both similarities and differences between males and females. She found that women apologize significantly more than men and those women apologize most to hearers of equal power while men apologize to women irrespective of status.

However, other researchers (e.g. Cameron, 1995, 1996.1997) have questioned these assertions, arguing that viewing men and women in a dichotomized way not only ignores the diversity of speech within groups of women and groups of men but also ignores cultural differences and those that may result from other social variables such as class, age, and ethnicity and, thus as (freed, 1995) puts it, serves to perpetuate stereotypes about male and female discourse.

\section{Methodology}

Participants \& instrumentation:

The present study emulates previous research which has examined the discourse of native speakers, sugimoto (1997), using questionnaires as a controlled data analysis technique: which can be readily submitted to statistical analysis.

The findings reveal that although apology strategies are universal, their conceptualization and verbalization vary across cultures.

The population of the study consists of all university undergraduate Persian literature students at Isfahan university the sample consisted of forty randomly selected students drawn from the Department of Literature .The respondents are relatively homogeneous in terms of their cultural background (Iranian), academic/ linguistic experiences (19-to 22-year - old undergraduates majoring in Persian literature) and gender (twenty males and twenty females).

The researcher designed a questionnaire based on Sugimoto's (1995) to compare the apology strategies used by male and female students, only gender was examined as a variable.

Since the questionnaire had already been piloted and checked for reliability, the researcher did not conduct a pilot study. The questionnaire consists of three parts:

1 - An introduction of the study and instruction for answering the questions

2 - A section for collecting demographic information about the participants.

$3-10$ sections each of which involves a situation which requires an apology

\section{Significance of the Study}

The present study is significant, probably because it explores an area of intercultural pragmatics that has not, to the best of the researcher's knowledge, been sufficiently explored for this topic and target group. It is hoped that the study will enrich the field of intercultural pragmatics, and that its findings will lend verification to the findings of previous research on apology strategies.

\section{Date Analysis}

The researcher identified the strategies used by the respondents and then classified then based on Sugimoto's (1997) strategies.

As noted above, these strategies were divided in to primary strategies, secondary strategies, and seldom used strategies.

The researcher started by tabulating the strategies used by the participants in order to identify the apology strategies they used.

The tabulation of the results made it possible for the researcher to determine the strategies used and whether or not Sugimoto's (1997) results apply to Iranian respondents. It further helped to clarify whether or not gender has an effect since previous research had reported that females apologize more than males. (Brown, 2001; Holmes, 1995).

In order to identify the apology strategies used, the researcher used two types of tables: one to clarify the method used to show remorse (the overt expression of apology), and another to show the other apology strategies employed in each situation and their percentages. The researcher attempted to list all the apology strategies used by the 
respondents.

One strategy that was not mentioned by Sugimoto (1997) or any other researcher is that in which the wrongdoer exonerates himself/ herself and instead blames the victim for what had happened. This strategy is not common within the realm of apologizing though. It is closely related to it.

Not only did the researcher tally the percentage of the apology strategies used, but she also calculated and compared the percentage of those used by male and female respondents in order to discover any potential differences which might be attributed to gender. It is worth noting here that the respondents had used a combination of apology strategies, which may have been part of their attempt to aptly express their remorse

\section{Findings and Discussion}

Sugimoto's (1997) strategies have been used as the basis of the analysis. Statement of remorse was the strategy most frequently used by male and female respondents across the sample. Thus, it is discussed separately prior to the collective discussion of the other strategies. Unlike Sugimoto, the researcher has tabulated the different manifestations of this strategy in terms of the use of expressions of apology and the various numbers of intensifiers.

\subsection{Apology Strategies Used by Male and Female Respondents}

In their attempt to respond to the situations given in the questionnaire (see the Appendix A). Respondents used the following apology strategies:

1. Statement of remorse. As all of the respondents used statements of remorse in almost all of the situations (with few exceptions for some of the situations), this type of strategy is discussed separately.

Respondents used the following manifestations of stating remorse

Using one expression of apology: In $30 \%$ of the situations $(n=60)$, male respondents used one expression of apology to show remorse. Expressions ranged from the word sorry to clauses such as excuse me, I apologize, Female respondents used these strategies in $20 \%$ of the situations $(n=40)$

Using one expression of apology and one intensifier: In $45 \%$ of the situations $(n=90)$, male respondents used the intensifier very with the word sorry, yielding expressions such as very sorry Female respondents used these strategies in $30 \%$ of the situation $(\mathrm{n}=60)$

Using one expression of apology and two intensifiers: In $20 \%$ of the situations ( $\mathrm{n}=40)$, male respondents used two intensifiers to produce an expression of apology to show remorse; this may be attributed to the respondents' need to use more than the word sorry to express how bad they felt for whatever happened. The intensifiers used were either a repetition of the word very in sentences such as I am very, very sorry females used this strategy in $25 \%(\mathrm{n}=50)$

D) Using two expressions of apology: In $0.5 \%$ of the situations $(n=19)$, male respondents used two expressions of apology resulting in responses such as sorry, excuse me.

Other apology strategies were used by respondents in their responses to the 10 items of the questionnaire. These are summarized in Table 2 and presented below according to their frequency of use. Even though the researcher used Sugimoto's (1997) apology strategies as the basis of her analysis, she has come up with other strategies not mentioned in the literature.

2. Accounts: In $30 \%$ of the situations $(n=60)$ male respondents and in $15 \%$ of the situations $(n=50)$ female respondents, in their attempt to apologize, used accounts to explain what had happened. This resulted in responses like the following for each of the items of the questionnaire, except Item 8 for which the respondents did not use accounts:

The wind was too strong it broke your umbrella (Item 1).

I have a family emergency and can not go to the concert (Item 2)

3. Compensation: In $20 \%$ of the situation $(n=40)$. Male respondents and in $20 \%$ of the situations $(n=40)$ female respondents used compensation where the wrongdoer tries to replace the damaged item or pay for it. The only items on the questionnaire that elicited the use of compensation were items 1, 9, 2, and 6 yielding responses such as:

Here is a new umbrella I got you to replace yours (Item1).

I will pay for the ticket if you do not find anybody to go with you (Item2)

4. Reparation: In $15 \%$ of the situations $(n=30)$, male respondents and in $10 \%$ of the situation $(n=20)$ female respondents used reparation strategy which allows them to repair the damage done to the item or the situation in question. All the items, except 1, 2, and 5, got responses that displayed reparation as shown in the following examples: 
I did not mean to be late. Let us have juice on me (item 3).

I will explain what happened to the teacher and get you an extension (Item 4)

5. Showing lack of intent to do harm: In $5 \%$ of the situations $(n=10)$, male respondents and in $20 \%$ of the situation $(n=40)$ female respondent felt the need to deny their intention to harm the offended. They attempted to show that whatever happened was accidental and not at all premeditated. Responses to all the questionnaire items, excluding 7 and 10, portrayed the use of this strategy as is evident in the following examples:

I did not mean to break your umbrella. I will buy you another (Item1)

I did not mean to break your date (Item, 2).

6. Assessment of responsibility: This category is divided in to two types:

a. Positive assessment of responsibility which refers to the wrongdoer's admission of having committed the act in question. In $5 \%$ of the situations $(n=10)$ male respondents and in $5 \%$ of the situation $(n=10)$ female respondents expressed their responsibility for what had happened. The only item warranting this was item 4 where the wrongdoer had forgotten his classmate's homework. It was my fault that you are in this dilemma was given in response

b. Negative assessment of responsibility which refers to the wrongdoer's denial of being responsible for the act in question. In $15 \%$ of the situations $(n=30)$, male respondents and in $10 \%$ of the situation $(n=)$ female respondents felt the need to deny responsibility or to blame others for the deed. Responses to items 1, 3-7 and 9 showed examples of this strategy as is evident from the following examples.

It was not my fault. The wind broke your old umbrella (Item 1).

I did not break your Walkman. It was old any way (Item 9).

7. Promise not to repeat offense: Male respondents promised not to repeat the act they were apologizing for in $0 \%$ of the situations $(\mathrm{n}=0)$ and female respondents in $10 \%$ of the situations $(\mathrm{n}=20)$. Responses to items 2,3 , and 8 reflect the use of this apology strategy, as shown in the examples below:

I will never play with things that do no concern me again (Item 8).

I promise to go with you next time (Item 2).

8. Asking victim not to be angry: Male respondents asked the offended not to be angry in $5 \%$ of the situation ( $\mathrm{n}=10)$ and females in $5 \%$ of the situation $(n=10)$ and females in $5 \%$ of the situations $(n=10)$. This strategy was only used in items 1,3 and 6 as shown in the examples below:

I hope you are not angry (Item2)

Don't be angry. I will get you another umbrella (Item 1)

9. Invoking Allah's (God's) name: Male respondents mentioned Allah's (God's) name in $0.5 \%$ and females in $15 \%$ of the situations in order to wish the offended better times, as shown in the following responses to items 1,4, and 8:

May Allah compensate you for your umbrella (Item I)?

May Allah help you write a new paper (Item 8)?

Tables 1 and 2 present summaries of the number and percentages of the strategies used by male and female respondents

\subsection{Differences in Apologies between Male and Female Respondents}

As seen from the figures in Tables 1 and 2 , Iranian male and female respondents differed in their use of apology strategies; this coincides with the findings of studies that present gender as and unimportant factor in people's use of speech acts in general, and apology strategies in particular (cf. Lukasik, 2000)

Although male and female respondents used the various manifestations of the statement of remorse, it was obvious the female respondents tended to use this strategy more, opting for the various manifestations of remorse in $25 \%$ of the situations compared to the male respondent's $5 \%$ this is consistent with the claim that females are trained from childhood to apologize more for their mistakes (cf. Brown, \& Attarde, 2000; Holmes, 1995)

The four primary strategies used by the male respondents were accounts, compensation reparation, negative assessment of responsibility $(30 \%, 20 \%, 15 \%, 15 \%$, respectively), while those used by female respondents were compensation, Showing lack of intent to do harm, accounts, reparation $(20 \%, 20 \%, 15 \%, 10 \%$, respectively)

Male respondents tended to use negative assessment of responsibility more than their females, counterparts (15\% 
and $5 \%$, respectively)

Female respondents used the strategy of promise not to repeat offense in $10 \%$ of the situations, while their male counterparts did not use this strategy at all.

\section{References}

Al-Zumor, Abdul Wahid. (2003). Apologies in Arabic and English: an international - language and cross - cultural study. [Online] Available: http://www.Lboro.Ac.Uk/departments/ea/politeness/apologiesinarabicandenglish.html (October $\left.13^{\text {th }}, 2011\right)$

Brown, J. D. (2001). Pragmatics tests: different purposes, different test. In: Rose, Kenneth R., \& Kasper, Gabriele (Eds), Pragmatics in Language Teaching. Cambridge University Press, Cambridge. pp. 301-325

Brown, Penelope, \& Levinson, Stephen C. (1978). Politeness: Some universals of Language Use. Cambridge University Press. Cambridge.

Brown, Steven, \& Attardo, Salvatore. (2000). Understanding Language Structure, Interaction, and Variation: An Introduction to Applied Linguistics and Sociolinguistics for Non specialists. Michigan University Press, Michigan.

Cameron, Deborah. (1995). Rethinking language and gender studies: some issues for the 1990s. In Mills, Sarah (Ed.), Language and Gender: Interdisciplinary Perspectives. Longman, New York, pp. 31-44

Cameron, Deborah. (1996). The language - gender interface: challenging co-optation. In: Bergvall, Victoria, Bing, Hanet, \& Freed, Alice (Eds.), Rethinking Language and Gender Research: Theory and Practice. Longman, New York. pp. 31-53

Caneron, Deborah. (1997). Performing gender identity: Young men's talk and the construction of heterosexual masculinity. In Johnson, Sally, Meinhof, \& Ulrke Hanna (Eds), Language and Masculinity. Blackwell, Oxford. pp. 47-64

Cordella, Marisa. (1990). Apologizing in Chilean Spanish and Australinan English: a cross - cultural perspective. ARAL Series, 5, 66-92

Freed, Alice F. (1995). Language and gender. Annual Review of Applied Linguistics, 153-220

Freed, B. (1995). Second language acquisition in a study abroad context. Amsterdam: John Benjamins.

Fromkin, Victoria, \& Rodman, Robert. (1988). An Introduction to Language. Holt, Rinehart and Winston, New York.

Garcla, Carmen. Apologizing in English: politeness strategies used by native and non - native speakers. Multilingual, 8, 3-20

Goffman, Erving. (1971). Remedial work. In: Goffman, Erving (Ed.), Relations in Public: The Micro politics of Public Order. Allen Lane, London.

Gooder, Haydie, Jacobs, Jacobs, \& Hane M. (2000). On the border of the unsayable: the apology in post colonizing Australia Interventions, 2, 229-247

Holmes, Janet. (1995). Sex differences and apologies: one aspect of communicative competence. In Brown, H. Douglas, \& Gonzo. Susan (Eds.), Readings on Second Language Acquisition. Prentice Hall Regents, Englewood Cliffs, New Jersey. pp. 362-385

Hudson, Thorn. (2001). Indicators for pragmatic instruction: some quantitative tools. In Rose, Kenneth R., \& Kasper, Gabriele (Eds), Pragmatics in Language Teaching. Cambridge University Press, Cambridge. pp. 301-325

Olshtain, Elite. (1983). Sociocultural competence and language transfer: the case of apology. In Gass, Susan M., \& Selinker, Larry (Eds), Language Transfer Language Learning. Newbury House, Rowley, MA. pp. 232-249

Olshtain, Elite. (1989). Apologies across cultures. In Blum- Kulka, Shoshana, House, Juliane, Kasper, Gabriele (Eds), Cross Cultural Pragmatics: Requests and Apologies. Ablex, Norwood, New Jersey. pp. 155-173

Olshtain, Elite, \& Cohen, Andrew. (1983). Apology: a speech act set. In wolfson, Nessa, Judd, Elliot (Eds) Sociolinguistics and Language Acquisition. Newbury House, Rowley, MA. pp. 18-35

Sugimoto, Naomi. (1997). A Japan-U.S. comparison of apology styles. Communication Research 24, 349-370. http://dx.doi.org/10.1177/009365097024004002

Suszczynska, Malgorzata. (1999). Apologizing in English, Polish and Hungarian: different languages, different strategies. Journal of Pragmatics, 31, 1053-1065. http://dx.doi.org/10.1016/S0378-2166(99)00047-8 
Trosborg, Anna. (1987). Apology strategies in native/ non- native English. Journal of Pragmatics, 11, 147-167. http://dx.doi.org/10.1016/0378-2166(87)90193-7

Table 1. A summary of the number and percentages of the types of the statement of remorse used by male and female respondents Type

\begin{tabular}{|l|l|l|l|l|}
\cline { 2 - 5 } \multicolumn{1}{c|}{} & \multicolumn{2}{l|}{} & \multicolumn{2}{l|}{} \\
\cline { 2 - 5 } \multicolumn{1}{c|}{} & Mroup & Females \\
\cline { 2 - 5 } \multicolumn{1}{c|}{} & Number & Percent & Number & Percent \\
\hline One expression of apology & 60 & 30 & 40 & 20 \\
\hline Two expression of apology & 10 & 5 & 50 & 25 \\
\hline $\begin{array}{l}\text { One expression of apology+one } \\
\text { intensifier }\end{array}$ & 90 & 45 & 60 & 30 \\
\hline $\begin{array}{l}\text { One expression of apology+Two } \\
\text { intensifier }\end{array}$ & 40 & 20 & 50 & 25 \\
\hline
\end{tabular}

Table 2. A summary of the number and percentages of the types of the apology strategies used by male and female respondents Strategy

\begin{tabular}{|l|l|l|l|l|}
\cline { 2 - 5 } \multicolumn{1}{c|}{} & \multicolumn{2}{l|}{ Group } & \multicolumn{2}{l|}{} \\
\cline { 2 - 5 } \multicolumn{1}{c|}{} & Males & \multicolumn{2}{l|}{ Females } \\
\cline { 2 - 5 } \multicolumn{1}{c|}{} & Number & Percent & Number & Percent \\
\hline Accounts & 60 & 30 & 30 & 15 \\
\hline Reparation & 30 & 15 & 20 & 10 \\
\hline Compensation & 40 & 20 & 40 & 20 \\
\hline Promise not to repeat offense & 0 & 0 & 20 & 10 \\
\hline Assessment of responsibility & & & & \\
\hline Negative & 30 & 15 & 20 & 10 \\
\hline Positive & 10 & 5 & 10 & 5 \\
\hline Asking victim not to be angry & 10 & 5 & 10 & 5 \\
\hline Showing lack of intent to do harm & 10 & 5 & 40 & 20 \\
\hline Invoking, Allah's(God's) name & 10 & 5 & 10 & 5 \\
\hline
\end{tabular}

\section{Appendix A: The questionnaire}

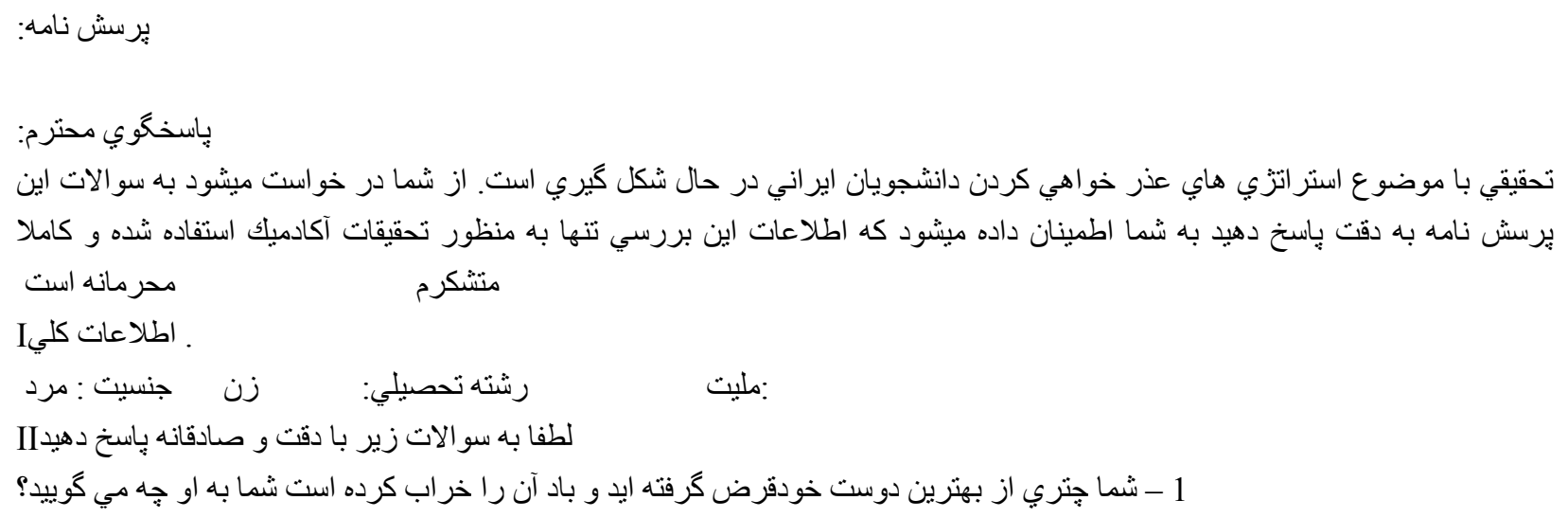


2 - شما برنامه ريزي كرده ايد كه با دوستان خود به كنسرت برويد و نتو انسته ايد سر قرار حاضر شويدو هنوز بول بليط را به آنها بدهكاريد

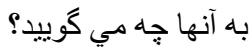

3 - شما برسرقرارملاقات كروهي كه با دوستانتان كذاشته بوديد يك ساعت دير ميرسيد به دوستنتان جه مي كوييد

4 - شما تكاليف درسي يكي از همكارسي هايتان را قرض كرفته ، تكاليف خود را تحويل داده ولي تكاليف دوستتان را به معلم تحويل نداده ايد به او جهه مي كويبد

5 - شما به دليل تصادف يكي از دوستانتان به قرار ملاقاتتان نمي رسيد به افر ادي كه با آنها قرارداشته جهه مي گويد

از هم اتاقي خود قرض كرفته ايد آن را به مدت 3 هفته بر نكردانده ايد ، به او جه مي كَييد؟CDما يك

7 - شما به دليل اشتباه متوجه شدن محل يا ساعت قرار ، به قرار ملاقات با دوستتان نمي رسيد به او جه مي كوييد؟

8-شما با كامبيونر دوستتان كار مي كرديدو مقاله مهي ر اكه او در طول دو هفته كذنته روي ان كار ميكرده است را پاك كرده ايد به او جه مي كوبيد

9 - شما ضبط صوت بر ادر يا خو اهرتان را قرض كرفته و آن را شكسته ايد به او جه ميكوييد؟

10 - شما يك قرار دسته جمعي را كنسل كرده و تمايل افر اد را سركردان كرده ايد به آن ها جه مي كوييد؟

مجدداً از همكاري شما متشكرم 